\title{
Status Paper \\ BUFFALOES FOR DAIRYING IN SOUTH ASIA: POTENTIAL, CHALLENGES AND WAY FORWARD
}

\author{
M.N.A. Siddiky ${ }^{1^{*}}$ and M.O. Faruque ${ }^{2}$ \\ ${ }^{1}$ SAARC Agriculture Centre, BARC Complex, Farmgate, Dhaka-1215, Bangladesh \\ ${ }^{2}$ Department of Animal Breeding and Genetics, Bangladesh Agricultural University \\ Mymensingh-2202, Bangladesh
}

\begin{abstract}
Buffalo is considered the dairy animal for $21^{\text {st }}$ century due to its higher adaptability and productivity in the changing climatic conditions. There is a large diversity in the buffalo genetic resources and South Asia is home of high yielding source promising buffalo breed of Murrah and Nail Ravi. South Asia is inhabitant of 151.49 million buffalo populations out of 194.29 million of global populations. Besides, about $79.74 \%$ of Asia and $77.9 \%$ of world buffalo populations are inhabitant in South Asian countries. During the last decade, the world buffalo population has been increased by approximately $1.49 \%$ annually. South Asia is currently producing 100.74 million metric tons of buffalo milk which is about 96.05 $\%$ of Asia and $93.19 \%$ of world buffalo milk production. The share of buffalo milk is around $51.07 \%$ of the total milk production of the South Asia. The contribution of buffalo milk in India, Nepal and Pakistan are $51.2 \%, 66.6 \%$ and $59.5 \%$ respectively in total milk production. Among the South Asian countries, maximum milk is produced by India followed by Pakistan, Nepal, Bangladesh, Sri Lanka and Bhutan. The productivity of buffalo has been recorded $410 \mathrm{~kg}^{-1}$ buffalo-1 year, $1880 \mathrm{~kg}^{-1}$ buffalo ${ }_{1}^{1}$ year, $1934 \mathrm{~kg}^{-1}$ buffalo ${ }^{-1}$ year and $867 \mathrm{~kg}^{-1}$ buffalo ${ }^{-1}$ year, $508 \mathrm{~kg}^{-1}$ buffalo 1 year in Bangladesh, India, Pakistan, Nepal and Sri Lanka respectively. Although most of the buffaloes are non-descript indigenous types and their production potential is not satisfactory. There are different production systems are prevailing such as zero input-low output, low input-medium output and high input-high output. Moreover, selective breeding for buffalo with the same breed under low input-medium output production system and grading up of non-descript buffaloes using improver breed/s under zero input-low output production system has been commonly practiced. The demand of milk has been increasing due to economic solvency and rapid pace of urbanization but most of the countries are deficit in production even it is challenging to meet the
\end{abstract}

\footnotetext{
*Corresponding author e-mail: nasiddiky.saarc@gmail.com
} 
projected demand to achieve the SDG by 2030. To increase the productivity through genetic improvement of buffaloes could be important thrust areas to obtain projected demand of milk. Productive and reproductive efficiency can only be improved by adopting suitable breeding policies and good management practices.

Keywords: Buffalo, dairying, milk, South Asia

\section{INTRODUCTION}

Buffalo is called the black gold of South Asia. Buffalo produces high quality, rich, creamier milk as well as lean meat with very low fat and cholesterol content. Its milk is suitable for specially dairy products owning to higher fat, lactose and solid not fat (SNF) contents. Buffaloes are resistant to several tropical diseases prevalent in South Asia, while enduring diverse harsh climates making it a preferred climate resilient livestock species. It has ensured survival for landless and small farmers in many parts of South Asia, while ushering fortunes for the elite buffalo breeders and entrepreneurs. Buffalo holds great hope for food security and poverty alleviation in South Asia, because of the largest population comprising diverse and the best buffalo germplasm of the world. Of the 194.29 million world buffalo population, $97 \%$ is concentrated in Asia and 57\% in India alone (FAO, 2014). The increasing importance and popularity of buffalo species in the world is evident from its increasing population trends over the last decades with about $1.13 \%$ in Asia, $0.92 \%$ in Africa, $1.74 \%$ in Americas and overwhelming 5.22\% in Europe (FAO, 2014). About 150 million households around the world are directly engaged in milk production involving primarily small and marginal households whereas almost the same number is indirectly involved in associated activities related to milk and meat which is the primary source of animal protein for human consumption. This region has a great biodiversity of buffalo germplasm, including the world famous buffaloes Murrah and Nili-Ravi - renowned for high milk production potential. The India and Pakistan share $69.32 \%$ and $23.19 \%$, of world buffalo milk production respectively (FAO, 2014). About $71.4 \%$ of world buffalo meat is produced in South Asian countries (FAO, 2014). Although buffalo is an essential part of livestock in South Asian countries but it has been neglected in some SAARC countries like Bangladesh, Bhutan and Sri Lanka.

\section{Buffalo population dynamics in South Asia}

According to FAO (2014) estimate, about $79.74 \%$ of Asia and $77.9 \%$ of world buffalo population are inhabitant in South Asia. The total buffalo population is around $34.80 \%$ of the total cattle and buffalo population in the region. In the region, buffalo population is highest in India followed by Pakistan, Nepal, Bangladesh, Sri Lanka and Bhutan. Buffalo population in Maldives and Afghanistan is not documented yet. Asian buffaloes dominate the world population, representing $92.52 \%$ of the worldwide population of 194.29 million (FAO, 2014). 


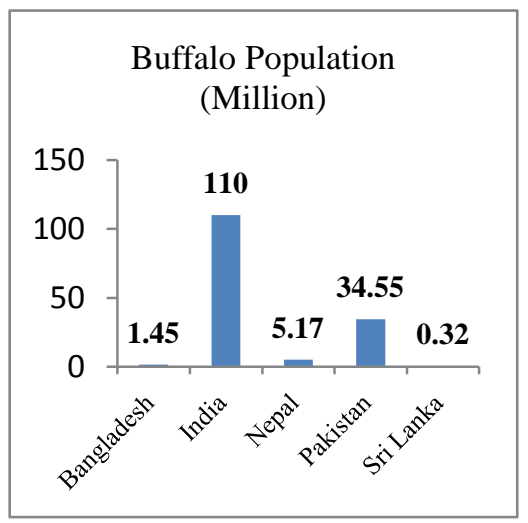

Figure 1. Buffalo population in South Asia

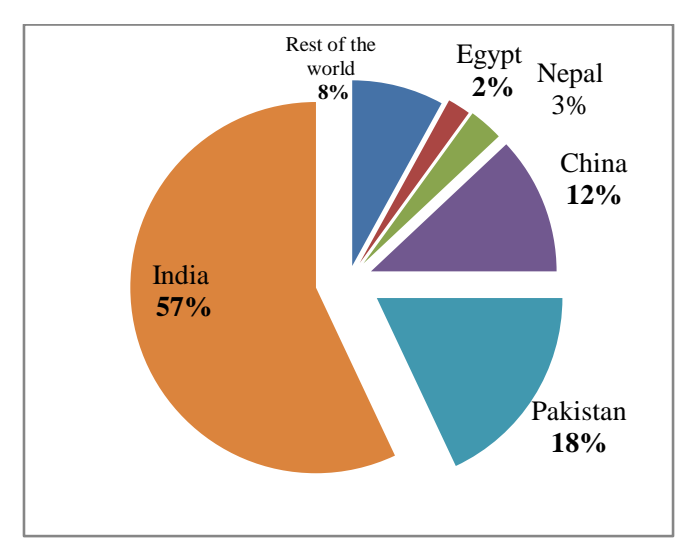

Figure 2. Buffalo population diversity in the world

Table 1. Buffalo populations in the world, in Asia and in South Asia

\begin{tabular}{ccc}
\hline Region/Country & Total population (million) & Share in world population (\%) \\
\hline World & 194.29 & $100 \%$ \\
Asia & 179.75 & $92.52 \%$ \\
India & 110.00 & $56.61 \%$ \\
Pakistan & 34.55 & $17.78 \%$ \\
Nepal & 5.17 & $2.66 \%$ \\
Bangladesh & 1.45 & $0.746 \%$ \\
Sri Lanka & 0.32 & $0.16 \%$ \\
Bhutan & 0.001 & - \\
\hline
\end{tabular}

Source: FAO, 2014; Chakravarty, 2013

Within the Asian region, about $79.74 \%$ of buffaloes are in South Asia and the rest $20.26 \%$ in other countries (Chakravarty, 2013). The buffalo populations in the world, in Asia and in South Asia are presented in table 1. During last decade, world buffalo population has increased by 20.0 million head and $89.41 \%$ of that increases occurred in Asia, in fact, that population growth has been largely contributed by India and Pakistan (FAO, 2014). According to latest livestock census, the buffalo populations are 1.45, 0.001, 110, 5.17, 34.55 and 0.32 millions in Bangladesh, Bhutan, India, Nepal, Pakistan and Sri Lanka respectively (Figure 1). The growth rate of buffalo population in the region was always in positive trend. In the region, total buffalo population was 121.18 million in 2000 and after the passage of time it became 151.49 million in 2014 (Table 2). 
Table 2. Growth rate of buffalo population in South Asia (2000-2014) In Million

\begin{tabular}{c|c|c|c|c|c|c}
\hline Year & Bangladesh & India & Nepal & Pakistan & Sri Lanka & Total \\
\hline 2000 & 0.89 & 93.83 & 3.5 & 22.66 & 0.30 & 121.18 \\
2002 & 0.97 & 96.53 & 3.7 & 24.03 & 0.28 & 125.51 \\
2004 & 1.06 & 99.72 & 3.9 & 25.50 & 0.30 & 130.48 \\
2006 & 1.16 & 103.42 & 4.2 & 27.33 & 0.31 & 136.42 \\
2008 & 1.26 & 106.01 & 4.4 & 29.00 & 0.31 & 140.98 \\
2010 & 1.34 & 107.37 & 4.8 & 29.41 & 0.42 & 143.34 \\
2012 & 1.44 & 108.70 & 5.13 & 32.68 & 0.41 & 148.36 \\
2014 & 1.45 & 110.00 & 5.17 & 34.55 & 0.32 & 151.49 \\
\hline
\end{tabular}

(Source: FAOSTAT)

\section{Buffalo genetic resources in South Asia}

Regional buffaloes are mostly riverine type $(2 n=50)$, however, some swamp type $(2 \mathrm{n}=48)$ are also available in some agro climatic zones viz. North eastern part of India and Bangladesh. This regional buffaloes comprises of indigenous non-descript, crossbred and pure breed. The genotypic and phenotypic analysis of buffalo genomics has not done properly except India. National Bureau of Animal Genetic Resources (NBAGR) of India has successfully completed phylogenetic analysis of 13 buffalo breeds. The status of buffalo genetic resources in the region are presented in table 3 (Siddiky et al., 2014).

Table 3. Documented buffalo genetic resources in South Asia

\begin{tabular}{l|l}
\hline Country & Documented buffalo genetic resources \\
\hline Bangladesh & $\begin{array}{l}\text { Indigenous local called Deshi, Nili Ravi, Murrah, crossbred and } \\
\text { swamp buffalo }\end{array}$ \\
Bhutan & Non descript, Hyakule, Kagye, Murrah, crossbred and wild \\
India (13 Breeds) & Non descript, Murrah, Nili-Ravi, Jaffarabadi, Banni, Mehsana \\
& Marathwada Nagpuri, Pandharpuri, Bhadawari, Surti, Toda, \\
& Chilika, Kalahandi, cross breed, swamp and wild \\
Nepal & Non descript, cross breed, Gaddi, Parkote and Lime and wild \\
Pakistan & Non descript, Nili-Ravi, Nili, Ravi, Kundhi and Azakheli \\
Sri Lanka & Non descript, crossbred, Lankan buffalo, wild buffalo and Murrah \\
\hline
\end{tabular}

(Source: Farm Animal Genetic Resources in SAARC Countries, 2014)

\section{Buffalo milk production in South Asia}

South Asia is currently producing 100.74 million metric tons of buffalo milk which is about $96.05 \%$ of Asia and $93.19 \%$ of world buffalo milk production (FAO, 2014). 
The share of buffalo milk is around $51.07 \%$ of the total milk production of the South Asia. The contribution of buffalo milk to the total milk production in the world is about $13 \%$. The contribution of buffalo milk in India, Nepal and Pakistan are 51.2\%, $66.6 \%$ and $59.5 \%$ respectively in total milk production (FAO, 2014). Among the South Asian countries, maximum milk is produced by India followed by Pakistan, Nepal, Bangladesh, Sri Lanka, and Bhutan. The total milk production scenarios in South Asia are presented in table 4.

\section{Productivity of buffalo in South Asia}

River buffalo produce more milk than the Swamp buffalo. Average lactation yield in the best known dairy breeds, Murrah and Nili-Ravi, is around 2000 litre (Agarwal \& Tomar, 1998) although elite buffalo with up to 6000 litre also exist in India, Italy and Pakistan, which indicates its great potential for milk production. The productivity of buffalo has been recorded $410 \mathrm{~kg}^{-1}$ buffalo ${ }^{-1}$ year, $1880 \mathrm{~kg}^{-1}$ buffalo ${ }^{-1}$ year, $1934 \mathrm{~kg}^{-}$ ${ }^{1}$ buffalo ${ }^{-1}$ year and $867 \mathrm{~kg}^{-1}$ buffalo ${ }^{-1}$ year, $508 \mathrm{~kg}^{-1}$ buffalo ${ }^{-1}$ year in Bangladesh, India, Pakistan, Nepal and Sri Lanka respectively (FAO, 2014). Highest productivity recorded in Pakistan and lowest in Bangladesh. The production potentiality of buffaloes in different countries is presented in table 4. According to production potentiality, it is observed that Pakistan and India has the highest milk producing buffaloes than others. Pakistani buffalo Nili-Ravi is the better performing buffalo in the world for milk production. The highest production recorded in elite herd is 2500 litre per 305 days lactation while average production at commercial herd is 18002500 litre per 322 days lactation (Pak Dairy Info, 2017). Average milk production of Pakistani buffaloes is 5-7 litre day-1. India is home to great biodiversity of buffalo germplasm, including the world famous Murrah buffaloes-renowned for high milk production potential. The average milk production of Indian buffaloes is 5-6 litre/day. The productivity of buffaloes in different countries are given in table 5 .

Table 4. Total milk production in South Asia

\begin{tabular}{c|c|c|c}
\hline Country & $\begin{array}{c}\text { Total Milk } \\
\text { Production (MMT) }\end{array}$ & $\begin{array}{c}\text { Buffalo Milk } \\
\text { Production (MMT) }\end{array}$ & $\begin{array}{c}\text { Percentage of } \\
\text { buffalo milk } \\
\text { (MMT) }\end{array}$ \\
\hline Bangladesh & 7.2 & 0.1 & 1.4 \\
India & 146 & 74.7 & 51.2 \\
Nepal & 1.8 & 1.2 & 66.6 \\
Pakistan & 42 & 25 & 59.5 \\
Sri Lanka & 0.25 & 0.045 & 18.0 \\
Total & 197.25 & 100.74 & \\
\hline
\end{tabular}

Source: FAO, 2014 \& Hamid et al., 2016 
Table 5. Average buffalo milk production in different countries

\begin{tabular}{c|c}
\hline Country & Average milk yield (kg/animal/year) \\
\hline Pakistan & 1934 \\
India & 1880 \\
Vietnam & 1000 \\
Nepal & 867 \\
Sri Lanka & 508 \\
China & 563 \\
Bangladesh & 410 \\
Italy & 815.9 \\
Asia & 1389 \\
\hline
\end{tabular}

\section{Buffalo milk quality}

Comparative milk composition in buffalo, cow and goat is given in table 6. Buffalo milk is healthy as it is richer in saturated fatty acids. It's much higher total solids (18-23\% vs. 13-16\%) is useful for making cheese, butter fat, several kinds of traditional sweets and ice creams. Swamp buffalo milk has even higher fat (9-15\%), protein $(7.1 \%)$, lactose $(4.90 \%)$ and ash $(0.89 \%)$ (Thac, 1979). Buffalo milk is especially important, and priced higher in Italy, for making Mozzarella cheese (Nanda and Nakao, 2003).

Table 6. Composition milk in buffalo, cow and goat

\begin{tabular}{l|c|c|c|c}
\hline Constituents & Buffalo & Cow & Goat & Skimmed Milk \\
\hline Moisture (gm) & 81.00 & 87.50 & 86.80 & 92.10 \\
Protein (gm) & 4.30 & 3.20 & 3.30 & 2.50 \\
Fat (gm) & 6.50 & 4.10 & 4.50 & 0.10 \\
Minerals (gm) & 0.80 & 0.80 & 0.80 & 0.70 \\
Carbohydrate (gm) & 5.00 & 4.40 & 4.60 & 4.60 \\
Energy calories (kCal) & 117.00 & 67.00 & 72.00 & 29.00 \\
Calcium (mg) & 210.00 & 120.00 & 170.00 & 120.00 \\
Phosphorus (mg) & 130.00 & 90.00 & 120.00 & 90.00 \\
Iron (mg) & 0.20 & 0.20 & 0.30 & 0.20 \\
\hline
\end{tabular}

Source: Gupta, 2001

\section{Buffalo genetic improvement}

Genetic improvement of large number of buffaloes under different stakeholders in South Asia demands on quality buffalo male germplasm. The easiest way of multiplication of superior germplasm and genetic improvement of buffalo could be 
done through artificial insemination (AI). The production of quality male germplasm should be through progeny testing programme. Lack of infrastructure especially lack of animal identification and recording system is the most limiting factor in this regard. In South Asia the animal breeding technology like AI are not even widely adopted because of non-availability of quality male buffalo germplasm at the door step of farmers, lack of breeding infrastructure, non-availability of quality fodders, lack of awareness of rural households and many other problems directly and indirectly associated with the genetic improvement of buffaloes. As a result, the productivity of buffalo is low in South Asia. The adoption of AI reduces the indiscriminate use of breeding bulls, inbreeding among animals and also the chance of reproductive problems of buffaloes due to various sexually transmitted diseases. The breeding policy would be

\section{A. For organized dairy farm}

1. Selective breeding of high producing buffalo using most adapted breeds in the institute/ commercial herds under high input-high output production system of the respective country.

2. Cross breeding improver breeds/s and inter se mating using crossbred buffaloes using in organized dairy farm under low input- medium output production system in each country.

B. Un-organized dairy farm

1. Selective breeding for buffalo with the same breed under low input- medium output production system of the respective country.

\section{Nutrition and health care}

To enhance productivity, farmers have to be given adequate awareness on balanced feeding of animals. The farmers will be supported with the supply of good quality seeds and seedlings to develop improved pasture where feasible. Farmers will be encouraged to utilize agricultural by- products to increase efficiency and reduce production cost. Awareness to farmers on fodder conservation crop residues enrichments technologies, contract fodder production to make fodder available for feeding the animals round the year will be pursued rigorously. Proactive animal health action plans to prevent infection and parasitic diseases as well as zoonosis and effective laboratory diagnostic services, timely monitoring shall be instituted within the existing regional and national laboratories.

\section{Advantages of buffalo husbandry over cattle}

\section{Work/Animal traction}

The water buffalo is an important beast of burden in Asian farming. It is widely used to plough, level land, plant crops, puddle rice fields, cultivate field crops, pump water, haul carts, sleds and shallow-draft boats. It is also used to carry people, thresh grain, press sugar cane, haul logs, and more. Buffalo have an advantage over other 
draught animals in wet or muddy areas, with their large hooves. Their legs can withstand wet conditions better than cattle. However they are not as fast as cattle, horses or mules. This puts them at a disadvantage in dryer areas. Therefore, the additional income every year through the sale of surplus milk is vital to their wellbeing and economic security (Agarwal \& Tomar, 1998). In India and Pakistan, male Riverine buffalo contribute to $6-12 \%$ and $1-2 \%$ of farm power, respectively, but provide much of the road haulage. Together with cattle, buffalo plough 30 million hectares of land in India (Nanda et al., 2002).

\section{Utilization of feeds: conversion of meat and milk}

The most important and desirable quality of the water buffalo is its extraordinary capacity of utilization less digestible feeds (straw, sugarcane wastes etc.) than cattle. So it requires less concentrate feeds than cattle. This mean that it can produce excellent quality food meat and milk using only crop residues, pasture, and mineral salts, without the addition of supplement concentrates (Hamid et al., 2016). The nutrient requirements of buffalo steer include $0.24 \mathrm{~kg}$ DCP, $1.8 \mathrm{~kg}$ TDN, $6.6 \mathrm{MCal}$ ME, $14 \mathrm{~g} \mathrm{Ca}$, and $11 \mathrm{~g} \mathrm{P}$. On adlibitum and high concentrate (75:25) based rations the growth rate is $610 \mathrm{~g} /$ day with feed efficiency of 7:1. On all roughage rations (Green berseem/ berseem hay) the growth rate is $370 \mathrm{~g} /$ day with feed efficiency of 10:1 (Ranjan and Pathak, 1979).

\section{Resistances to diseases}

Buffalo is high adaptable and healthily animal that can resist infectious and contagious diseases. However, they must receive the same vaccines, hygienic care and dedicated attention, as like as cattle. Buffaloes have higher degree of resistance and tolerance than cattle against many diseases (Deb et al., 2016).

\section{Soil fertility}

Buffalo enrich soil structure and fertility while tracking paddy field. Each year, an adult buffalo produce 4-6 tones of wet manure plus additional urine as bio-fertilizer. This reduces the requirement of chemical fertilizers as well provide soil humus that chemical cannot provide.

\section{Resistance to climatic hazard}

Buffalo can survive against tidal wave better than any other livestock species. This is evidence from the cycles that occurs frequently in the coastal area of Bangladesh. Buffalo is the species that can easily survive in coastal ecosystem. Buffalo can be considered one of the suitable options for livelihood improvement in coastal areas (Faruque, 2016).

\section{Housing}

Buffalo do not require expensive houses as like cattle. It can even live in open air throughout the year. For $99 \%$ of buffaloes in Bangladesh, there is no house at all. This is true in many parts of world including South Asia (Faruque, 2016). 


\section{Inherent qualities as meat producer}

Buffaloes have a unique ability to utilise coarse feeds, straws and crop residues converting them into protein rich lean meat. Hence buffaloes fit well in poor countries having poor feed resources. Buffalo properly managed and fed as a meat producing animal and slaughtered at 16 to 20 months of age yields a highly satisfactory top quality meat at a much lower cost than the cattle (Ranjan and Pathak, 1979). Since buffaloes have been used as draught animals for centuries, they have evolved with exceptional muscular development. Until recently, little thought was given to use them exclusively for meat production. Buffaloes are lean animals. The sub-cutaneous fat layer of the carcass is usually thinner than that on comparably fed cattle. Fat is low even under feed lot conditions. More lean and less fat compared to cattle, has created a demand for it among health conscious consumers (Kondaiah, 2002).

\section{Increasing popularity of buffalo}

The popularity of buffalo dairy farming is increasing day by day in the Indo-Pak subcontinent due to following reasons (Singh, 2013)

- Quick acclimatization to varied climates

- Efficiently thrives on poor forage/ roughage

- Less prone to prevalent diseases than crossbred cows

- Better marketability of surplus males and females

- Better productivity than most indigenous cow breeds

- Higher consistency of milk production

- Better taste and healthy milk-fetches higher price

- Higher fat \& SNF - more suitable for sweet meat, yogurt, and cheese making.

Constraints of buffalo development in South Asia

Singh et al. (2013 and Hamid et al. (2016) pointed out the following constrains for development of buffaloes in SAARC region:

- Lack of high yielding buffalo breed in SAARC region except India and Pakistan. The indigenous buffaloes are low producers

- Lack of sufficient number of proven bulls

- Lack of breeding infrastructure

- lack of animal identification and recording system

- Slow adoption of AI and other reproductive biotechnology

- Lack of long-term breed development policy and research programme

- Scarcity of quality feeds, fodder and pasture land 
- Higher calf mortality

- Seasonality of reproduction

- Impact of global warming

- Lack of knowledge about the quality of buffalo milk and meat

- Lack of public awareness about buffalo husbandry

- Lack of technical skills about buffalo production of farm holders

- Lack of coordination within research and government organizations, universities, NGOs and beneficiaries

\section{Recommendations of buffalo development in South Asia:}

\section{Support product processing and marketing facilities}

More dairy groups will be formed and encouraged to take up buffalo farming and they will be supported with required product processing, diversification and marketing facilities. The dairy groups/cooperatives will be supported for establishment of vital infrastructures such as milk collection centers for collection and marketing of fresh milk, milk processing units for collection and processing of local dairy products and dairy sales counter in every town for marketing of products. Through periodic market information and research, preferred dairy products from buffalo milk will be explored. There is an opportunity for the production of mozzarella cheese from buffalo milk. There are feasible small to medium scale processing plants will be encouraged to diversify such products.

\section{Capacity building}

The farmers and extension workers lack skills and knowledge in improved buffalo breeding and husbandry practices. Need assessment will be done and training will be imparted to national and field including farmers on buffalo breeding and improved buffalo husbandry practices. Routine disease screening and preventive health care will be emphasized through timely up-dation of skill and knowledge of field staff. National Buffalo Information and Recording System (NBIS) shall be instituted which will ensure traceability for performance recording, disease outbreaks and will help in instituting progeny testing program in the long run. Where possible, awareness and sensitization will be given and farmers will be encouraged to form breeders groups and association to produce quality animals which will form the basis for sustainability of buffalo farming in the country.

Knowledge and skill of national professional will be enhanced to take up research and development works and a provision within national buffalo breeding program shall be created for communication of research findings to the farmers to enhance production. To strengthen networking mechanism and institutional linkages among the buffalo research and production centers within the region, with Asian and world buffalo federations for exchange of gemplasm, scientist visits and information 
exchange on latest research and development works can improve and sustain buffalo farming in the region.

\section{Long term intervention areas for buffalo breed improvement program}

The combination of AI with Multiple Ovulation and Embryo Transfer (MOET) as advanced reproductive bio-technology approach shall be initiated in a long run which can immensely enhance the rate of genetic gain and productivity in buffalo population. The application of other bio-technologies such as embryo manipulation (splitting, sexing and cloning) for faster multiplication of superior germplasm from highly selected elite donors and facilitate to achieve the target of producing large number of superior bull calves/bulls and their adequate number of quality semen doses are other promising breeding options available for application. Molecular genetic studies for identification of genes of interest (milk quality and quantity traits and Marker Assisted Selection (MAS) are other breeding tools available for identification of superior animals and commercial exploitation of genetic potential of indigenous breeds. Besides, MOET, there may be a limited application of other advanced breeding tools for buffalo breeding in the region.

Considering the constrains and present socio-economic trends in buffalo production and marketing, the following suggestions are being considered:

- Develop/strengthen breeding infrastructure in the region.

- In intensive production system, continuous up gradation of native buffaloes in the plain land with imported semen of Murrah, Nili-Ravi or Mediterranean breed.

- In semi-intensive production system, crossbreeding of native buffaloes with Murrah or Nili Ravi and fixed $50 \%$ exotic bloods followed by inter se mating.

- In low input production system, selective breeding should be followed.

- $\quad$ Feeding, disease preventive measures and other husbandry practices should be addressed properly.

- Quality fodder seed production farms should be established. Increase the land for fodder production should be ensured.

- $\quad$ Reproductive biotechnology should be utilized.

- $\quad$ Public awareness for benefit of buffalo production and buffalo milk and meat should be created by different media; Radio like TV, newspaper etc.

- $\quad$ Buffalo milk and meat market and infrastructure should be developed.

- Development of skill manpower by technical training should be ascertained.

- National research and international collaboration should be strengthened.

- Private investment is to be explored and encouraged to invest in buffalo development infrastructure including marketing of milk and meat products in the country. 


\section{CONCLUSION}

The buffalo dairying in the region is characterized by small-scale, scattered and unorganized buffalo holders; low productivity; inadequate and inappropriate animal feeding and health care; lack of assured year-round remunerative price for milk production; inadequate basic infrastructure for provision of production inputs and services; inadequate basic infrastructure for procurement, transportation, processing and marketing of milk; and lack of professional management. Low productivity of dairy buffaloes is a serious constraint to dairy development in the region. The productivity of dairy buffaloes could be increased by adoptive appropriate breeding strategies. The breeding policy should not only focus on milk yield but should also provide for the production of good quality breeding bulls. Selective breeding with high yielding purebreds, such as Murrah, Nili Ravi, should be given high priority in their home tract and same may be practices for buffaloes maintained under low input system.

\section{REFERENCES}

Agarwal, S.K., and Tomar, O.S. (1998). Reproductive Technologies in Buffaloes. Indian Veterinary Research Institute, Izatnagar, India.

Chakravarty, A.K. (2013). Strategies for genetic improvement of buffaloes through production of quality male germplasm in SAARC countries. Paper presented in the seminar on "High Yielding Dairy Buffalo Breed" at SAARC Agriculture Centre, Dhaka on December, 2013.

Deb, G.K., Nahar, T.N., Duran, P.G., and Presicce, G.A. (2016). Safe and sustainable traditional production: The water buffalo in Asia. Frontiers in Environmental Science, 4, p.1-7.Doi: 10.3389/fenvs.2016.00038.

FAO. (2014). FAOSTAT Database. Food and Agriculture Organization of the United Nations, Rome, Italy. Available at: http://faostat.fao.org/.

Faruque, M.O. (2016). Buffalo production in Bangladesh. Asian Buffalo Magazine, Jan-Dec. $1-7$.

Gupta, S. (2001). Handbook of dairy formulations processes and milk processing industries. Engineers India Research Institute, New Delhi

Hamid, M.A., Siddiky, M.N.A., Rahman, M.A., and Hossain, K.M.(2016).Scopes and opportunities of buffalo farming in Bangladesh: A Review. SAARC Journal of Agriculture, 14(2), 63-77.

Kondaiah, N. (2002). Meat and by products. In: Handbook of Animal Husbandry. $3^{\text {rd }}$ ed. (Ed. P.S, Dharma). New Delhi, India: DIPA, ICAR, p. 950-975.

Nanda, A.S., Brar, P.S., and Jain, A.K. (2002). Management of buffalo reproduction in India. Proceedings of the First Buffalo Congress of Americas, 16-17 May, Belem Para, Brazil.

Nanda, A.S., and Nakao, T. (2003). Role of buffalo in the socioeconomic development of rural Asia: Current status and future prospectus. Animal Science Journal, 74, 443-455. 
Pak Dairy Info, 2017. Pakistan first online dairy farming guide. Retrieved on 24 November 2017 from http://www.pakdairyinfo.com/niliravi.htm

Ranjan, S.K., and Pathak, N.N. (1979). Management and feeding of buffaloes. Vikas Publishing House, New Delhi, India.

Siddiky, M.N.A., and Tareque, A.M.M. (eds). (2014). Farm Animal Genetic Resources in SAARC Countries: Diversity, Conservation and Management. SAARC Agriculture Centre, Dhaka, Bangladesh, p. 1-431.

Siddiky, M.N.A. (ed). (2015). SAARC Dairy Outlook. SAARC Agriculture Centre, Dhaka, Bangladesh, p. 1-160.

Singh, I. (2013). Buffalo production in India. Paper presented in the seminar on "High Yielding Dairy Buffalo Breed" at SAARC Agriculture Centre, Dhaka on December, 2013.

Thac, N.D. (1979). Results of studies on F1 crossbreed of Murrah and Vietnamese local buffaloes. Agricultural Publishing House, Hanoi, Vietnam. Results of Research on Science and Technology (1969-1979), p. 154-163. 